\title{
Keterampilan Berbicara Murid Kelas V Min Seutui Banda Aceh Melalui Kegiatan Sosiodrama
}

\author{
Putry Julia $^{1}$, Rahmani ${ }^{1}$, Fitria Mandasari ${ }^{2}$ \\ ${ }^{1}$ Dosen Fakultas Keguruan dan Ilmu Pendidikan Universitas Serambi Mekkah \\ ${ }^{2}$ Alumni Fakultas Keguruan dan Ilmu Pendidikan Universitas Serambi Mekkah \\ Email.putryjulia@serambimekkah.ac.id
}

\begin{abstract}
Abstrak
Penelitian ini bertujuan untuk mengetahui dan mendeskripsikan tingkat keterampilan berbicara murid kelas V MIN Seutui Banda Aceh dengan melalui kegiatan sosiodrama. Subjek penelitian ini adalah siswa kelas V MIN Seutui Banda Aceh tahun ajaran 2016/2017 yang berjumlah 36 siswa dan jumlah semua subjek tersebut dijadikan sebagai sampel. Penelitian ini bersifat deskriptif dengan pendekatan kualitatif dengan jumlah subjek penelitian berjumlah 36 siswa. Penelitian ini dilaksanakan pada tanggal 15 November 2016. Data dikumpulkan melalui tes dengan bentuk tes yang digunakan untuk mengukur keterampilan berbicara melalui kegiatan sosiodrama siswa adalah tes lisan, yang kemudian di analisis dengan menggunakan rumus statistik sederhana (Presentase). Hasil penelitian ini diperoleh bahwa nilai tertinggi yang dicapai oleh siswa adalah 95 dan nilai terendah 78. Jika dilihat keterampilan siswa, terdapat 10 orang $(27,8 \%)$ siswa yang tingkat keterampilannya berada pada kategori sangat baik, 26 orang $(72,2 \%)$ siswa berada pada kategori baik dan tidak ada keterampilan siswa yang berada pada kategori sedang dan kurang. Dengan melihat keterampilan berbicara siswa melalui kegiatan sosiodrama yang berada pada kategori baik, serta menciptakan suasana yang aktif, kondusif, dan meningkatkan motivasi siswa maka kegiatan sosiodrama dapat diterapkan dalam pembelajaran bahasa Indonesia pada materi lain yang dianggap sesuai dapat diterapkan.
\end{abstract}

\section{Kata Kunci : Keterampilan Berbicara, Metode Sosiodrama}

\section{PENDAHULUAN}

Keterampilan berbicara (speaking skill) merupakan salah satu aspek dari keterampilan berbahasa selain keterampilan menyimak (listening skill), keterampilan membaca (reading skill), dan kemampuan menulis (writing skill). Keempat aspek tersebut saling berhubungan satu dengan yang lainnya. "Berbicara adalah kemampuan mengucapkan bunyi-bunyi artikulasi atau kata-kata untuk mengekspresikan, menyatakan serta menyampaikan pikiran, gagasan dan perasaan" (Tarigan, 2008:15).

Keterampilan berbahasa khususnya pada kemampuan berbicara merupakan keterampilan kebahasaan yang sangat penting. Syafi'ie (2002:33) "mengemukakan dengan keterampilan berbicaralah pertama-tama kita memenuhi kebutuhan berkomunikasi dengan masyarakat tempat kita berada".

Kurikulum Tingkat Satuan Pendidikan (KTSP) Sekolah Dasar (SD) dan Madrasah Ibtidaiyah (MI) pada salah satu Standar Kompetensi (SK) untuk siswa kelas V Semester satu khususnya aspek berbicara adalah sebagai berikut; mengungkapkan 148 
pikiran, pendapat, fakta secara lisan dengan menanggapi suatu persoalan, menceritakan hasil pengamatan, atau berwawancara (Depdiknas, 2006:327).

Selain pentingnya keterampilan berbicara untuk berkomunikasi, komunikasi dapat berlangsung secara efektif dan efisien dengan menggunakan bahasa, sedangkan hakikat bahasa adalah ucapan. "Proses pengucapan bunyi-bunyi bahasa itu tidak lain adalah berbicara. Untuk dapat berbicara dengan baik diperlukan keterampilan berbicara" (Syafi'ie 2002:33).

Berdasarkan hasil observasi di lapangan, serta wawancara yang peneliti lakukan dengan guru Bahasa Indonesia di MIN Seutui Banda Aceh, didapatkan informasi bahwa dengan menggunakan metode sosiodrama, minat dan motivasi siswa menjadi meningkat, hal ini tentu saja sangat berpengaruh terhadap peningkatan kemampuan siswa. Dengan menerapkan metode sosiodrama, pembelajaran yang biasanya monoton, diharapkan anak terangsang untuk menggunakan daya indera penglihatannya dan pendengarannya secara maksimal untuk menyimak cerita yang diperankan, daya imajinasi anak akan muncul selaras dengan alur dan tokoh dalam cerita, dan akhirnya anak diharapkan dapat berbicara dengan baik dan benar.

Berdasarkan uraian di atas, maka peneliti merasa tertarik untuk melakukan suatu penelitian dengan judul "Keterampilan Berbicara Murid Kelas V MIN Seutui Banda Aceh Melalui Kegiatan Sosiodrama". Tujuan Penelitian

Tujuan yang hendak dicapai dalam penelitian ini yaitu untuk mengetahui dan mendeskripsikan tingkat keterampilan berbicara murid kelas V MIN Seutui Banda Aceh melalui kegiatan sosiodrama.

\section{KAJIAN PUSTAKA}

\section{Pembelajaran Bahasa Indonesia}

Menurut Depdiknas (2006:417) Tujuan mata pelajaran Bahasa Indonesia yang tercantum dalam KTSP pada SD/MI adalah:

a. Berkomunikasi secara efektif dan efisien sesuai dengan etika yang berlaku secara lisan maupun tulisan

b. Menghargai bangsa menggunakan Bahasa Indonesia sebagai bahasa persatuan dan bahasa Negara.

c. Memahami Bangsa Indonesia dan menggunakannya dengan tepat dan kreatif untuk berbagai tujuan.

d. Menggunakan Bahasa Indonesia untuk meningkatkan emosional dan sosial

e. Menikmati dan memanfaatkan karya sastra untuk memperluas wawasan, memperhalus budi pekerti, serta meningkatkan pengetahuan dan berbahasa.

f. Menghargai dan membanggakan sastra.

Berdasarkan pendapat yang telah diuraikan di atas dapat disimpulkan bahwa Bahasa Indonesia merupakan bahasa persatuan yang menjadi identitas bangsa Indonesia. Untuk menjaga kelestarian dan kemurnian bahasa Indonesia maka diperlukan berbagai upaya. Contoh upaya untuk menjaga kemurnian bahasa Indonesia adalah menuliskan kaidah-kaidah ejaan yang disempurnakan (EYD). Dapat digunakan sebagai pedoman dalam kegiatan berkomunikasi menggunakan bahasa Indonesia dengan benar, baik berkomunikasi secara langsung maupun tidak langsung. Sedangkan 
upaya lain yang dapat digunakan untuk melestarikan bahasa Indonesia adalah dengan menanamkan bahasa Indonesia sejak dini.

\section{Metodologi Pembelajaran Bahasa}

Strategi meliputi pendekatan, metode, dan teknik. Pendekatan adalah konsep dasar yang melingkupi metode dengan cakupan teoritis tertentu. Metode merupakan jabaran dari pendekatan. Satu pendekatan dapat dijabarkan ke dalam berbagai metode. Metode adalah prosedur pembelajaran yang difokuskan ke pencapaian tujuan. Dari metode, teknik pembelajaran diturunkan secara aplikatif. Satu metode dapat daplikasikan melalui berbagai teknik pembelajaran. Teknik adalah cara konkret yang dipakai saat proses pembelajaran berlangsung. Guru dapat berganti-ganti teknik meskipun dalam koridor metode yang sama (Sunender, 2008:54).

Pembelajaran bahasa Indonesia di tingkat Sekolah Dasar (SD) dapat dilaksanakan dengan berbagai macam pendekatan. Misalnya dengan pendekatan komunikatif dan pendekatan konstektual. Menurut Sanjaya (2006:127) bahwa "pendekatan dapat diartikan sebagai titik atau sudut pandang kita terhadap proses pembelajaran". Komunikasi tidak selalu bersifat formal atau resmi tetapi juga mungkin bersifat tidak formal. Karena itu bahan pengajaran tidak hanya ditekankan kepada ragam baku tetapi juga ragam lainnya. Bahan pengajaran bahasa harus sesuatu yang bermakna bagi siswa. Hal ini diwujudkan dalam pemilihan bahan pengajaran yang berkaitan dengan ragam-ragam komunikasi seperti tersebut di atas.

\section{Pembelajaran Keterampilan Berbicara}

Keterampilan berbicara merupakan salah satu keterampilan berbahasa yang harus dikuasai siswa karena kompetensi keterampilan berbicara adalah komponen terpenting dalam tujuan pembelajaran bahasa Indonesia. Berbicara sebagai salah satu dari empat keterampilan berbahasa memiliki peran yang sangat penting dalam berkomunikasi. Pembelajaran bahasa Indonesia diarahkan untuk meningkatkan siswa agar mampu berkomunikasi, baik secara lisan maupun tertulis. Selain untuk meningkatkan siswa agar mampu berkomunikasi, pembelajaran bahasa Indonesia bertujuan agar siswa memiliki sikap positif yaitu mau menggunakan bahasa Indonesia dengan baik dan benar dalam berkomunikasi. Komponen yang paling penting dalam berkomunikasi adalah keterampilan berbicara. Nurhadi (2005: 342) menjelaskan bahwa "berbicara merupakan salah satu aspek kemampuan berbahasa yang berfungsi untuk menyampaikan informasi secara lisan. Berbicara berarti mengemukakan ide atau pesan lisan secara aktif. Dalam menyampaikan pesan, informasi yang disampaikan harus mudah dipahami oleh orang lain agar terjadi komunikasi secara lancar”.

\section{Tujuan Berbicara}

Berkaitan dengan standar kompetensi mata pelajaran bahasa dan sastra Indonesia SD, pada keterampilan berbicara bertujuan agar siswa mampu mengungkapkan pikiran, pendapat, gagasan, dan perasaan secara lisan (Depdiknas, 2004:5).

Setiap kegiatan berbicara yang dilakukan manusia selalu mempunyai maksud dan tujuan. Menurut Tarigan (2008:15) tujuan utama berbicara adalah. 
"Untuk berkomunikasi. Komunikasi merupakan pengiriman dan penerimaan pesan atau berita antara dua orang atau lebih sehingga pesan yang dimaksud dapat dipahami. Oleh karena itu, agar dapat menyampaikan pesan secara efektif, pembicara harus memahami apa yang akan disampaikan atau dikomunikasikan. Tarigan juga mengemukakan bahwa berbicara mempunyai tiga maksud umum yaitu untuk memberitahukan dan melaporkan (to inform), menjamu dan menghibur (to entertain), serta untuk membujuk, mengajak, mendesak dan meyakinkan (to persuade)".

\section{Metode Pembelajaran}

KBBI (2001: 740) menyatakan metode yaitu "cara yang digunakan untuk melaksanakan suatu pekerjaan agar tercapai sesuai dengan yang dikehendaki". Selain itu, juga didefanisikan sebagai cara kerja yang bersistem untuk memudahkan pelaksanaan suatu kegiatan guna mencapai tujuan yang ditentukan. Dalam pembelajaran bahasa indonesia metode diartikan sebagai sisitem perencanaan pembelajaran bahasa indonesia secara menyeluruh untuk memilih, mengorganisasikan, dan meyajikan materi pelajaran bahasa indonesia secara teratur. Metode bersifat prosedural artinya, penerapan pembelajaran bahasa Indonesia harus dikerjakan menurut langkah-langkah yang teratur, bertahap yakni mulai perencanaan pembelajaran, penyajian sampai dengan penilaian dan hasil belajar.

\section{Jenis-Jenis Simulasi}

Adapun jenis-jenis metode simulasi yang dikemukakan Hasibuan (2006:27) adalah "berbentuk role playing psikodrama, sosiodrama, dan permainan". Jenis-jenis metode simulasi yang lain menurut Hyman dalam Hasibuan (2006: 27) adalah "termasuk ke dalam kelompok role playing. Bentuk-bentuk role playing yang lain adalah sosoidrama, permainan, dan dramatisasi”.

Adapun jenis-jenis metode simulasi yang dikemukakan Sanjaya (2006: 160161) adalah sebagai berikut.

1) Sosiodrama

2) Psikodrama

3) Role playing

\section{Metode Sosiodrama}

Metode berasal dari Bahasa Yunani "Methodos" yang berarti "cara atau jalan yang ditempuh. Sehubungan dengan upaya ilmiah, maka metode menyangkut masalah cara kerja untuk dapat memahami objek yang menjadi sasaran ilmu yang bersangkutan" (Hamalik, 2007:25).

Seorang guru dalam proses pembelajaran tentu tidak dapat lepas dari penggunaan metode-metode pembelajaran. Metode pembelajaran adalah "suatu pengetahuan tentang cara-cara yang digunakan guru untuk menyajikan bahan pelajaran kepada siswa di dalam kelas, baik secara individual atau secara kelompok agar pelajaran yang disampaikan dapat terserap, dipahami dan dimanfaatkan oleh siswa dengan baik" (Ahmadi dan Prasetya, 2005:52). Jadi seorang guru harus pandai memilih metode pembelajaran yang tepat agar tujuan pembelajaran dapat tercapai. 
"Kita mengenal bermacam-macam metode pembelajaran, baik yang tradisional maupun modern. Salah satu metode tersebut adalah metode sosiodrama. Metode sosiodrama adalah metode pembelajaran dengan mendemonstrasikan masalah-masalah sosial" (Ahmadi dan Prasetya, 2005:65). Sosiodrama adalah suatu kelompok yang bertindak memecahkan masalah terutama pemecahan masalah yang berkenaan dengan hubungan antar insani. Masalah itu dapat dihubungkan dengan kerja sama siswa di sekolah, keluarga, atau masyarakat umumnya. "Sosiodrama memberikan kesempatan kepada siswa untuk menyelidiki alternatif pemecahan masalah yang berkenaan dengan keluarga" (Hamalik, 2002: 138). Pembelajaran sosiodrama secara prinsipil dapat juga diartikan sebagai pembelajaran role playing atau bermain peran, dimana penggunaan istilah terhadap keduanya dapat disilihgantikan, sebagaimana ditegaskan Sudjana (2009:84) yang mengemukakan bahwa: "metode sosiodrama dan role playing dapat dikatakan sama artinya. Dimana tingkah laku didramatisasi dalam hubungannya dengan masalah sosial".

\section{METODE PENELITIAN}

\section{Waktu Penelitian}

Penelitian ini dilaksanakan di MIN Seutui Banda Aceh yang beralamat di jalan Sultan Alaidin Djohansyah lorong taqwa No. 36 dan dilakukan pada tanggal 15 November tahun 2016.

\section{Subjek Penelitian}

Meleong (2010: 132) "mendeskripsikan subjek penelitian sebagai informan, yang artinya orang pada latar penelitian yang dimanfaatkan untuk memberikan informasi tentang situasi dan kondisi latar penelitian". Subjek pada penelitian ini adalah siswa kelas V MIN Seutui Banda Aceh yang berjumlah 36 siswa, dengan laki-laki 14 siswa dan perempuan 22 siswa.

\section{Teknik Pengumpulan Data}

Adapun teknik yang digunakan dalam mengumpulkan data dalam penelitian ini adalah tes dan observasi.

\section{Teknik Pengolahan dan Analisis Data}

Teknik analisis data merupakan cara yang digunakan untuk menguraikan keterangan-keterangan atau data yang diperoleh agar data tersebut dapat dipahami bukan saja oleh orang yang mengumpulkan data tapi juga oleh orang lain. Setelah data dikumpulkan kemudian data tersebut diolah dengan menggunakan analisis statistik sederhana, yaitu dengan menggunakan rumus statistik (persentase) yang digunakan untuk mendeskripsikan hasil penelitian dengan rumus sebagai berikut:

$$
\mathrm{P}=\frac{f}{n} \times 100 \%
$$

Keterangan :

$$
\begin{aligned}
& \mathrm{P}=\text { Persentase } \\
& \mathrm{f}=\text { Frekuensi }
\end{aligned}
$$


$\mathrm{n}=$ Sampel

( Sudijono, 2001: 40)

\section{HASIL PENELITIAN DAN PEMBAHASAN \\ Hasil Tes Siswa}

Adapun hasil tes siswa kelas V MIN Seutui Banda Aceh tentang keterampilan berbicara siswa melalui kegiatan sosiodrama berdasarkan hasil penelitian, maka dapat dilihat bahwa, nilai yang tertinggi yang mampu dicapai siswa adalah 95, hanya 1 orang $(2,7 \%)$ siswa dan nilai terendah adalah 78 yang hanya 3 orang $(8,3 \%)$ siswa. Jika dilihat dari kategori keterampilan siswa, terdapat 10 orang $(27,8 \%)$ siswa yang tingkat keterampilannya berada pada kategori sangat baik, 26 orang $(72,2 \%)$ siswa berada pada kategori baik, dan tidak ada keterampilan siswa yang berada pada kategori sedang dan kurang.

\section{Rekapitulasi Nilai Tes Keterampilan Berbicara}

a. Nilai Tes Pada Aspek Kebahasaan

Tabel Rekapitulasi Nilai Hasil Tes Keterampilan Berbicara Melalui Kegiatan Sosiodrama Kelas VB MIN Seutui Banda Aceh Tahun 2016 Pada Aspek Kebahasaan

\begin{tabular}{|c|c|c|c|c|c|}
\hline \multirow{3}{*}{ No } & \multirow{3}{*}{ Nama } & \multicolumn{4}{|c|}{ Aspek yang dinilai } \\
\hline & & \multicolumn{4}{|c|}{ Aspek Kebahasaan } \\
\hline & & $\overline{\mathbf{K U}}$ & PTN & PKD & PK \\
\hline 1. & $\mathrm{AM}$ & 8,5 & 9,0 & 9,0 & 9,0 \\
\hline 2. & $\mathrm{DAG}$ & 8,5 & 8,0 & 8,5 & 8,0 \\
\hline 3. & $\mathrm{DM}$ & 9,0 & 9,0 & 8,5 & 9,0 \\
\hline 4. & FF & 7,5 & 8,0 & 7,5 & 7,5 \\
\hline 5. & $\mathrm{~K}$ & 7,5 & 7,5 & 8,0 & 8,0 \\
\hline 6. & $\mathrm{KH}$ & 9,0 & 9,0 & 9,5 & 9,5 \\
\hline 7. & KA & 7,5 & 8,0 & 7,5 & 7,5 \\
\hline 8. & MNF & 8,0 & 8,0 & 8,0 & 8,0 \\
\hline 9. & MA & 7,5 & 8,0 & 8,0 & 8,0 \\
\hline 10. & MFA & 9,5 & 9,5 & 9,5 & 9,0 \\
\hline 11. & $\mathrm{MF}$ & 9,0 & 9,0 & 9,0 & 9,0 \\
\hline 12. & MRH & 9,0 & 9,0 & 8,5 & 9,0 \\
\hline 13. & MR & 8,0 & 7,5 & 7,5 & 8,0 \\
\hline 14. & MA & 9,0 & 9,5 & 9,0 & 9,5 \\
\hline 15. & $\mathrm{M}$ & 8,5 & 8,5 & 9,0 & 9,0 \\
\hline 16. & $\mathrm{NZ}$ & 9,5 & 9,0 & 9,5 & 9,5 \\
\hline 17. & $\mathrm{NG}$ & 8,5 & 8,0 & 8,5 & 8,5 \\
\hline 18. & QS & 9,5 & 9,5 & 9,5 & 9,5 \\
\hline 19. & $\mathrm{QZ}$ & 9,0 & 8,5 & 8,5 & 9,0 \\
\hline 20. & $\mathrm{R}$ & 7,5 & 8,0 & 7,5 & 8,0 \\
\hline 21. & RM & 9,5 & 9,5 & 9,0 & 9,5 \\
\hline
\end{tabular}




\begin{tabular}{|l|l|l|l|l|l|}
\hline 22. & RA & 8,0 & 7,5 & 7,5 & 8,0 \\
\hline 23. & RS & 9,5 & 9,5 & 9,5 & 9,5 \\
\hline 24. & SA & 9,5 & 9,5 & 9,5 & 9,0 \\
\hline 25. & SF & 8,5 & 8,5 & 8,5 & 8,0 \\
\hline 26. & SN & 8,0 & 8,0 & 8,0 & 8,0 \\
\hline 27. & SH & 9,5 & 9,5 & 9,5 & 9,5 \\
\hline 28. & TMH & 9,5 & 9,5 & 9,5 & 9,5 \\
\hline 29. & TSA & 9,0 & 9,0 & 9,0 & 9,0 \\
\hline 30. & U & 8,0 & 8,0 & 8,5 & 8,5 \\
\hline 31. & UD & 9,0 & 9,0 & 8,5 & 9,0 \\
\hline 32. & VM & 7,5 & 8,0 & 7,5 & 8,0 \\
\hline 33. & Y & 8,0 & 8,5 & 8,5 & 8,5 \\
\hline 34. & YSB & 7,5 & 7,5 & 7,5 & 8,0 \\
\hline 35. & ZZ & 8,0 & 8,0 & 7,5 & 7,5 \\
\hline 36. & ZA & 9,0 & 8,5 & 9,0 & 9,0 \\
\hline
\end{tabular}

Keterangan:

$\mathrm{KU}$

Ketepatan Ucapan

PTN : $\quad$ Penempatan Tekanan dan Nada

PKD : : Pilihan Kata (diksi )

PK : Pemakaian Kalimat

b. Nilai Tes Pada Aspek Non Kebahasaan

Tabel Rekapitulasi Nilai Hasil Tes Keterampilan Berbicara Melalui Kegiatan Sosiodrma Kelas VB MIN Seutui Banda Aceh Tahun 2016

Pada Aspek Non Kebahasaan

\begin{tabular}{|c|l|c|c|c|c|c|c|}
\hline \multirow{2}{*}{ No } & \multirow{2}{*}{ Nama } & \multicolumn{6}{|c|}{ Aspek yang dinilai } \\
\cline { 3 - 8 } & & \multicolumn{5}{|c|}{ Aspek Non-Kebahasaan } \\
\cline { 3 - 8 } & & SYW & PM & GMT & VS & KLC & PTP \\
\hline 1. & AM & 8,5 & 8,5 & 9,0 & 9,0 & 9,0 & 9,0 \\
\hline 2. & DAG & 8,0 & 8,5 & 8,5 & 8,5 & 8,5 & 8,0 \\
\hline 3. & DM & 9,0 & 8,5 & 9,0 & 9,0 & 9,0 & 8,5 \\
\hline 4. & FF & 8,0 & 8,0 & 8,0 & 8,5 & 8,0 & 8,0 \\
\hline 5. & K & 8,5 & 8,0 & 8,0 & 7,5 & 8,0 & 8,0 \\
\hline 6. & KH & 9,5 & 9,5 & 9,5 & 9,5 & 9,0 & 9,5 \\
\hline 7. & KA & 8,5 & 8,0 & 8,0 & 8,0 & 8,0 & 8,0 \\
\hline 8. & MNF & 8,5 & 7,5 & 7,5 & 8,0 & 8,0 & 8,0 \\
\hline 9. & MA & 8,0 & 7,5 & 8,0 & 8,0 & 7,5 & 8,0 \\
\hline 10. & MFA & 9,5 & 9,0 & 9,5 & 9,5 & 9,5 & 9,5 \\
\hline 11. & MF & 9,0 & 9,0 & 9,0 & 9,0 & 8,5 & 8,5 \\
\hline 12. & MRH & 9,0 & 9,0 & 8,5 & 9,0 & 9,0 & 9,0 \\
\hline 13. & MR & 8,0 & 8,0 & 8,0 & 8,0 & 8,0 & 7,5 \\
\hline 14. & MA & 9,5 & 9,5 & 9,5 & 9,5 & 9,5 & 9,0 \\
\hline
\end{tabular}




\begin{tabular}{|l|l|l|l|l|l|l|l|}
\hline 15. & M & 9,0 & 9,0 & 8,5 & 9,0 & 9,0 & 9,0 \\
\hline 16. & NZ & 9,5 & 9,5 & 9,5 & 9,0 & 9,5 & 9,0 \\
\hline 17. & NG & 8,5 & 8,5 & 8,0 & 8,0 & 8,5 & 8,5 \\
\hline 18. & QS & 9,5 & 9,0 & 9,5 & 9,5 & 9,0 & 9,0 \\
\hline 19. & QZ & 9,0 & 9,0 & 8,5 & 9,0 & 9,0 & 9,0 \\
\hline 20. & R & 8,5 & 7,5 & 7,5 & 8,0 & 8,0 & 8,0 \\
\hline 21. & RM & 9,5 & 9,5 & 9,5 & 9,5 & 9,5 & 9,0 \\
\hline 22. & RA & 8,0 & 8,0 & 8,0 & 7,5 & 8,0 & 7,5 \\
\hline 23. & RS & 9,5 & 9,0 & 9,0 & 9,5 & 9,5 & 9,0 \\
\hline 24. & SA & 9,5 & 9,0 & 9,5 & 9,5 & 9,5 & 9,0 \\
\hline 25. & SF & 8,5 & 8,0 & 8,5 & 8,0 & 8,5 & 8,5 \\
\hline 26. & SN & 8,5 & 8,5 & 8,5 & 8,5 & 8,5 & 8,0 \\
\hline 27. & SH & 9,5 & 9,5 & 9,5 & 9,5 & 9,5 & 9,5 \\
\hline 28. & TMH & 9,5 & 9,0 & 9,5 & 9,5 & 9,5 & 9,5 \\
\hline 29. & TSA & 9,0 & 9,0 & 8,5 & 9,0 & 8,5 & 9,0 \\
\hline 30. & U & 8,5 & 8,5 & 8,5 & 8,0 & 8,5 & 8,5 \\
\hline 31. & UD & 9,0 & 8,5 & 9,0 & 9,0 & 9,0 & 8,5 \\
\hline 32. & VM & 8,0 & 8,0 & 8,0 & 8,0 & 7,5 & 7,5 \\
\hline 33. & Y & 8,5 & 8,5 & 8,0 & 8,5 & 8,0 & 8,5 \\
\hline 34. & YSB & 8,0 & 8,0 & 8,0 & 8,0 & 8,0 & 7,5 \\
\hline 35. & ZZ & 8,5 & 8,0 & 7,5 & 7,5 & 8,0 & 8,0 \\
\hline 36. & ZA & 9,0 & 9,0 & 8,5 & 9,0 & 9,0 & 9,0 \\
\hline
\end{tabular}

Keterangan :

SYW : Sikap yang wajar

PM : Pandangan mata

GMT : Gerak-gerik mimik yang tepat

VS : Volume suara

KLC : Kelancaran

PTP : Penguasaan topik.

c. Rekapitulasi Nilai Tes Keterampilan Berbicara

Tabel Rekapitulasi Nilai Hasil Tes Keterampilan Berbicara Melalui Kegiatan Sosiodrama Kelas V MIN Seutui Banda Aceh Tahun 2016

\begin{tabular}{|c|c|c|c|c|c|c|c|c|c|c|c|c|}
\hline \multirow{3}{*}{$\begin{array}{l}\mathrm{N} \\
\mathrm{O}\end{array}$} & \multirow{3}{*}{ Nama } & \multicolumn{10}{|c|}{ Aspek Yang Dinilai } & \multirow{3}{*}{ Jumlah } \\
\hline & & \multicolumn{4}{|c|}{ Aspek Kebahasaan } & \multicolumn{6}{|c|}{ Aspek Non-Kebahasaan } & \\
\hline & & $\mathrm{KU}$ & PTN & PKD & $\mathrm{PK}$ & SYW & $\mathrm{PM}$ & GMT & $\mathrm{VS}$ & KLC & PTP & \\
\hline 1. & $\mathrm{AM}$ & 8,5 & 9,0 & 9,0 & 9,0 & 8,5 & 8,5 & 9,0 & 9,0 & 9,0 & 9,0 & 88,5 \\
\hline 2. & DAG & 8,5 & 8,0 & 8,5 & 8,5 & 8,0 & 8,5 & 8,5 & 8,5 & 8,5 & 8,0 & 83,5 \\
\hline 3. & DM & 9,0 & 9,0 & 8,5 & 9,0 & 9,0 & 8,5 & 9,0 & 9,0 & 9,0 & 8,5 & 88,5 \\
\hline 4. & FF & 7,5 & 8,0 & 7,5 & 7,5 & 8,0 & 8,0 & 8,0 & 8,5 & 8,0 & 8,0 & 79 \\
\hline 5. & $\mathrm{~K}$ & 7,5 & 7,5 & 8,0 & 8,0 & 8,5 & 8,0 & 8,0 & 7,5 & 8,0 & 8,0 & 79 \\
\hline 6. & $\mathrm{KH}$ & 9,0 & 9,0 & 9,5 & 9,5 & 9,5 & 9,5 & 9,5 & 9,5 & 9,0 & 9,5 & 93,5 \\
\hline 7. & KA & 7,5 & 8,0 & 7,5 & 7,5 & 8,5 & 8,0 & 8,0 & 8,0 & 8,0 & 8,0 & 79 \\
\hline 8. & MNF & 8,0 & 8,0 & 8,0 & 8,0 & 8,5 & 7,5 & 7,5 & 8,0 & 8,0 & 8,0 & 79,5 \\
\hline 9. & MA & 7,5 & 8,0 & 8,0 & 8,0 & 8,0 & 7,5 & 8,0 & 8,0 & 7,5 & 8,0 & 78,5 \\
\hline 10 & MFA & 9,5 & 9,5 & 9,5 & 9,0 & 9,5 & 9,0 & 9,5 & 9,5 & 9,5 & 9,5 & 94 \\
\hline
\end{tabular}




\begin{tabular}{|c|l|c|c|c|c|c|c|c|c|c|c|c|}
\hline 11 & MF & 9,0 & 9,0 & 9,0 & 9,0 & 9,0 & 9,0 & 9,0 & 9,0 & 8,5 & 8,5 & 89 \\
\hline 12 & MRH & 9,0 & 9,0 & 8,5 & 9,0 & 9,0 & 9,0 & 8,5 & 9,0 & 9,0 & 9,0 & 89 \\
\hline 13 & MR & 8,0 & 7,5 & 7,5 & 8,0 & 8,0 & 8,0 & 8,0 & 8,0 & 8,0 & 7,5 & 78,5 \\
\hline 14 & MA & 9,0 & 9,5 & 9,0 & 9,5 & 9,5 & 9,5 & 9,5 & 9,5 & 9,5 & 9,0 & 93,5 \\
\hline 15 & M & 8,5 & 8,5 & 9,0 & 9,0 & 9,0 & 9,0 & 8,5 & 9,0 & 9,0 & 9,0 & 88,5 \\
\hline 16 & NZ & 9,5 & 9,0 & 9,5 & 9,5 & 9,5 & 9,5 & 9,5 & 9,0 & 9,5 & 9,0 & 93,5 \\
\hline 17 & NG & 8,5 & 8,0 & 8,5 & 8,5 & 8,5 & 8,5 & 8,0 & 8,0 & 8,5 & 8,5 & 83,5 \\
\hline 18 & QS & 9,5 & 9,5 & 9,5 & 9,5 & 9,5 & 9,0 & 9,5 & 9,5 & 9,0 & 9,0 & 93,5 \\
\hline 19 & QZ & 9,0 & 8,5 & 8,5 & 9,0 & 9,0 & 9,0 & 8,5 & 9,0 & 9,0 & 9,0 & 88,5 \\
\hline 20 & R & 7,5 & 8,0 & 7,5 & 8,0 & 8,5 & 7,5 & 7,5 & 8,0 & 8,0 & 8,0 & 78,5 \\
\hline 21 & RM & 9,5 & 9,5 & 9,0 & 9,5 & 9,5 & 9,5 & 9,5 & 9,5 & 9,5 & 9,0 & 94 \\
\hline 22 & RA & 8,0 & 7,5 & 7,5 & 8,0 & 8,0 & 8,0 & 8,0 & 7,5 & 8,0 & 7,5 & 78 \\
\hline 23 & RS & 9,5 & 9,5 & 9,5 & 9,5 & 9,5 & 9,0 & 9,0 & 9,5 & 9,5 & 9,0 & 93,5 \\
\hline 24 & SA & 9,5 & 9,5 & 9,5 & 9,0 & 9,5 & 9,0 & 9,5 & 9,5 & 9,5 & 9,0 & 93,5 \\
\hline 25 & SF & 8,5 & 8,5 & 8,5 & 8,0 & 8,5 & 8,0 & 8,5 & 8,0 & 8,5 & 8,5 & 83,5 \\
\hline 26 & SN & 8,0 & 8,0 & 8,0 & 8,0 & 8,5 & 8,5 & 8,5 & 8,5 & 8,5 & 8,0 & 82,5 \\
\hline 27 & SH & 9,5 & 9,5 & 9,5 & 9,5 & 9,5 & 9,5 & 9,5 & 9,5 & 9,5 & 9,5 & 95 \\
\hline 28 & TMH & 9,5 & 9,5 & 9,5 & 9,5 & 9,5 & 9,0 & 9,5 & 9,5 & 9,5 & 9,5 & 94,5 \\
\hline 29 & TSA & 9,0 & 9,0 & 9,0 & 9,0 & 9,0 & 9,0 & 8,5 & 9,0 & 8,5 & 9,0 & 89 \\
\hline 30 & U & 8,0 & 8,0 & 8,5 & 8,5 & 8,5 & 8,5 & 8,5 & 8,0 & 8,5 & 8,5 & 83,5 \\
\hline 31 & UD & 9,0 & 9,0 & 8,5 & 9,0 & 9,0 & 8,5 & 9,0 & 9,0 & 9,0 & 8,5 & 88,5 \\
\hline 32 & VM & 7,5 & 8,0 & 7,5 & 8,0 & 8,0 & 8,0 & 8,0 & 8,0 & 7,5 & 7,5 & 78 \\
\hline 33 & Y & 8,0 & 8,5 & 8,5 & 8,5 & 8,5 & 8,5 & 8,0 & 8,5 & 8,0 & 8,5 & 83,5 \\
\hline 34 & YSB & 7,5 & 7,5 & 7,5 & 8,0 & 8,0 & 8,0 & 8,0 & 8,0 & 8,0 & 7,5 & 78 \\
\hline 35 & ZZ & 8,0 & 8,0 & 7,5 & 7,5 & 8,5 & 8,0 & 7,5 & 7,5 & 8,0 & 8,0 & 78,5 \\
\hline 36 & ZA & 9,0 & 8,5 & 9,0 & 9,0 & 9,0 & 9,0 & 8,5 & 9,0 & 9,0 & 9,0 & 89 \\
\hline Jumlah & 308 & 308,5 & 307,5 & 311,5 & 316,5 & 309 & 309,5 & 312 & 311,5 & 307,5 & $3,101.5$ \\
\hline Rata-rata & 8,6 & 8,6 & 8,5 & 8,7 & 8,8 & 8,6 & 8,6 & 8,7 & 8,7 & 8,5 & 86,1 \\
\hline
\end{tabular}

Keterangan :

KU : Ketepatan ucapan

PTN : Penempatan tekanan dan nada

PKD : Pilihan kata (diksi)

PK : Pemakaian kalimat

SYW : Sikap yang wajar

PM : Pandangan mata

GMT : Gerak-gerik mimik yang tepat

VS : Volume suara

KLC : Kelancaran

PTP : Penguasaan topik.

Berdasarkan tabel di atas dapat dilihat bahwa nilai rata-rata tertinggi yang mampu dicapai siswa pada tes keterampilan berbicara adalah 8,8 dan terdapat pada aspek non-kebahasaan, yaitu pada aspek sikap yang wajar. Nilai terendah yang diperoleh siswa adalah 8,5 dan terdapat pada aspek kebahasaan yaitu pada aspek pilihan kata (diksi) dan non-kebahasaan yaitu pada aspek penguasaan topik. Sedangkan nilai rata-rata keseluruhan adalah 86,1 atau berada pada kategori baik. Sesuai dengan nilai KKM untuk mata pelajaran bahasa Indonesia yang ditetapkan di MIN Seutui Banda Aceh yaitu 80 maka secara klasikal nilai hasil tes untuk keterampilan berbicara siswa sudah berada pada kategori tuntas. Selanjutnya jika dilihat secara individual, nilai 
ketuntasan siswa juga sudah berada pada kategori tuntas, karena nilai terendah yang diperoleh siswa adalah 8,5, dan melewati nilai KKM untuk mata pelajaran bahasa Indonesia yang ditetapkan MIN Seutui Banda Aceh yaitu 80.

\section{Pembahasan}

Penelitian ini dilaksanakan pada tanggal 15 November 2016 di MIN Seutui Banda Aceh. Sesuai dengan tujuan penelitian ini, yaitu untuk mengetahui dan mendeskripsikan tingkat keterampilan berbicara murid kelas V MIN Seutui dengan melalui kegiatan sosiodrama, maka pembahasan dalam penelitian ini juga akan dibatasi sebatas pada keterampilan berbicara melalui kegiatan sosiodrama.

Berdasarkan hasil penelitian dan olah data di atas, diketahui bahwa tingkat keterampilan berbicara siswa kelas V MIN Seutui Banda Aceh berada pada kategori baik. Pada Tabel 4.1 di atas dapat diihat bahwa, nilai yang tertinggi yang mampu dicapai siswa adalah 95, dan nilai terendah adalah 78. Dari 36 orang siswa, terdapat 10 orang $(27,8 \%)$ siswa yang tingkat keterampilan berbicaranya pada kategori sangat baik, dan 26 orang $(72,2 \%)$ siswa yang tingkat keterampilan berbicaranya berada pada kategori baik.

Syafi'ie (2002:33) mengatakan bahwa keterampilan berbicara sangat diperlukan untuk berkomunikasi, komunikasi dapat berlangsung secara efektif dan efisien dengan menggunakan bahasa. Sedangkan Tarigan (2008:15) bahwa berbicara merupakan suatu sistem tanda-tanda yang dapat didengar (audible) dan yang kelihatan (visible) yang memanfaatkan sejumlah otot tubuh manusia demi maksud dan tujuan gagasan atau ideide yang dikombinaskan.

Berbicara bukan sekedar menghafal kosa kata. Langkah awal dalam pembelajaran berbicara dengan menggunakan metode sosiodrama adalah guru dapat memilih suatu topik yang dapat didramatisasikan, kemudian guru menyuruh siswa untuk berbicara di depan kelas yang berisi topik dari drama tersebut.

Roestiyah (2001:1) mengemukan bahwa "metode yang digunakan harus disesuaikan dengan materi yang disampaikan". Pada kenyataannya, cara atau metode mengajar yang digunakan guru untuk menyampaikan informasi kepada siswa berbeda dengan cara yang ditempuh untuk memantapkan siswa dalam menguasai pengetahuan, keterampilan serta sikap. Begitu juga dengan metode yang digunakan, untuk memotivasi siswa agar mampu menggunakan pengetahuannya untuk memecahkan suatu masalah yang dihadapi atau untuk menjawab suatu pertanyaan tertentu, akan berbeda dengan metode yang digunakan untuk tujuan agar siswa mampu berpikir dan mengemukakan pendapatnya sendiri dalam menghadapi berbagai persoalan.

Roestiyah (2001:90) melanjutkan bahwa "dengan menggunakan metode sosiodrama siswa dapat mendramatisasikan tingkah laku, atau ungkapan gerak-gerik wajah seseorang dalam hubungan sosial antar manusia, atau siswa dapat memainkan peranan dalam dramatisasi masalah sosial atau psikologis itu".

Melalui metode sosiodrama dalam berbicara, siswa dapat menghayati cerita yang diceritakannya, dan mampu menempatkan diri dalam situasi cerita yang sedang dibicarakannya. Ia dapat belajar watak orang lain, cara bergaul dengan orang lain, bagaimana cara mendekati dan berhubungan dengan orang lain, dan dalam situasi tersebut mereka harus dapat memecahkan masalahnya. Melalui metode ini siswa 
menjadi mengerti bagaimana cara menerima pendapat orang lain. Siswa juga harus bisa berpeendapat, memberikan argumentasi dan mempertahankan pendapatnya. Jika diperlukan dapat mencari jalan keluar atau berkompromi dengan orang lain jika terjadi banyak perbedaan pendapat. Lebih bagus jika siswa mampu mengambil kesimpulan atau keputusan dari tiap-tiap persoalan (Roestiyah 2001:90-91).

Berbicara melalui kegiatan sosiodrama menjadi alternatif untuk meningkatkan keterampilan berbicara. Dengan metode sosiodrama siswa dapat belajar mendramatisasikan sebuah masalah sosial kemudian menceritakannya di depan kelas dengan cara berbicara dengan menggunakan bahasa yang baik dan benar. Ketika melakukan proses ini siswa secara langsung praktik mengajarkan kata per kata dan per kalimat sehingga siswa lebih mudah memahami.

Pada kegiatan sosiodrama, siswa dapat mendramatisasikan tingkah laku, atau ungkapan gerak-gerik wajah seseorang dalam hubungan sosial antar manusia, atau siswa dapat memainkan peranan dalam dramatisasi masalah sosial atau psikologis itu. Hal ini terihat efektif dalam meningkatkan keterampilan berbicara siswa kelas V MIN Seutui Banda Aceh belum terlihat, karena belum ada tes khusus untuk menilainya, namun dengan kegiatan sosiodrama yang diterapkan, keterampilan berbicara siswa kelas V MIN Seutui BandaAceh terlihat baik.

Nilai rata-rata siswa pada setiap aspek yang dinilai juga berada pada kategori baik, dari 10 aspek yang dinilai, nilai rata-rata tertinggi yang dicapai siswa 8,8 dan terendah adalah 8,5. Dengan demikian, berdasarkan hipotesis yang diajukan dalam penelitian ini, yaitu "melalui metode sosiodrama, keterampilan berbicara murid kelas $\mathrm{V}$ MIN Seutui Banda Aceh lebih baik" dapat diterima kebenarannya, hal ini dengan melihat nilai rata-rata keseluruhan adalah 86,1 atau berada pada kategori kemampuan baik. Sesuai dengan nilai KKM untuk mata pelajaran bahasa Indonesia yang ditetapkan di MIN Seutui Banda Aceh yaitu 80 maka secara klasikal nilai hasil tes untuk keterampilan berbicara siswa sudah berada pada kategori tuntas. Selanjutnya jika dilihat secara individual, nilai ketuntasan siswa juga sudah berada pada kategori tuntas, karena nilai terendah yang diperoleh siswa adalah 8,5 dan melewati nilai KKM untuk mata pelajaran bahasa Indonesia yang ditetapkan MIN Seutui Banda Aceh yaitu 80 .

Untuk lebih jelasnya, rata-rata keterampilan siswa pada aspek berbicara dapat dilihat pada gambar grafik berikut ini.

\section{Gambar Grafik Nilai Rata-Rata Keterampilan Siswa MIN Seutui Banda Aceh} Pada Setiap Aspek Berbicara 


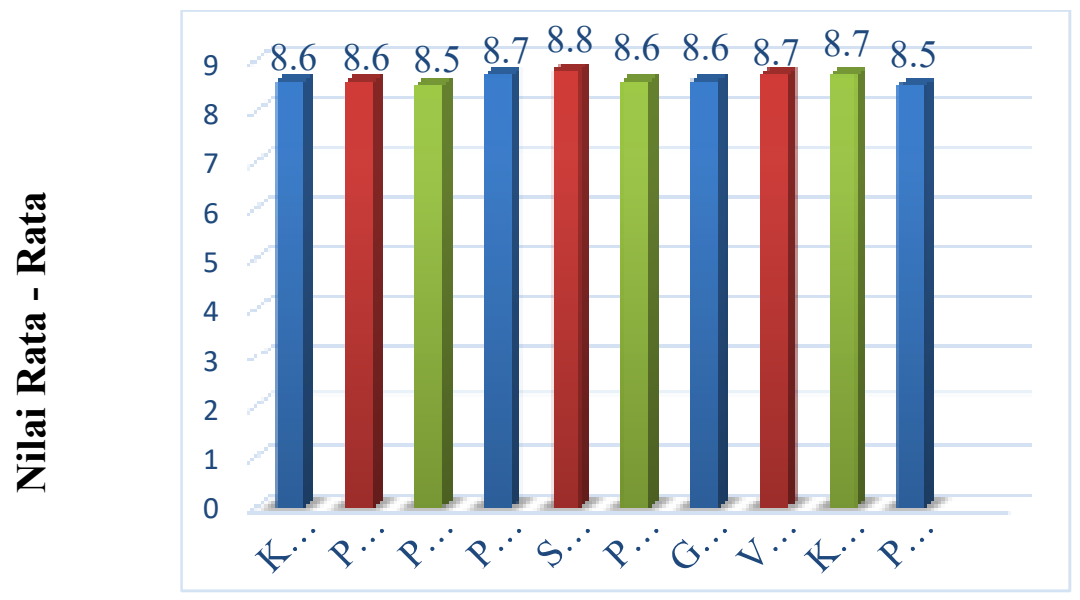

Aspek Yang Dinilai

Keterangan :

$\begin{array}{ll}\text { KU } & : \text { Ketepatan ucapan } \\ \text { PTN } & : \text { Penempatan tekanan dan nada } \\ \text { PKD } & : \text { Pilihan kata (diksi) } \\ \text { PK } & : \text { Pemakaian kalimat } \\ \text { SYW } & : \text { Sikap yang wajar } \\ \text { PM } & : \text { Pandangan mata } \\ \text { GMT } & : \text { Gerak-gerik mimik yang tepat } \\ \text { VS } & : \text { Volume suara } \\ \text { KLC } & : \text { Kelancaran } \\ \text { PTP } & : \text { Penguasaan topik. }\end{array}$

Dari 2 aspek yang dinilai, yaitu aspek kebahasaan dan non kebahasaan, keterampilan siswa terlihat lebih baik pada aspek non-kebahasaan, nilai rata-rata keterampilan siswa pada aspek non-kebahasaan adalah 8,7. Sedangkan nilai rata-rata keterampilan siswa pada aspek kebahasaan adalah 8,6.

Nilai rata-rata tertinggi yang mampu dicapai siswa terdapat pada aspek nonkebahasaan yaitu pada aspek sikap yang wajar. Pada aspek ini nilai rata-rata siswa adalah 8,8 . Sedangkan nilai rata-rata terendah yang diperoleh siswa berada pada aspek kebahasaan yaitu pada pilihan kata (diksi) dan pada aspek non-kebahasaan yaitu pada aspek penguasaan topik. Pada aspek ini rata-rata siswa adalah 8,5.

Berdasarkan hasil wawancara peneliti dengan guru yang bersangkutan, aspek non-kebahasaan para siswa dipengaruhi oleh sikap inisiatif dan rasa percaya diri para siswa tersebut. Sehingga pada tes keterampilan berbicara melalui kegiatan sosiodrama ini, keterampilan non-kebahasaan siswa lebih menonjol bila dibandingkan dengan keterampilan kebahasaan.

Di samping itu, guru yang bersangkutan juga mengemukakan bahwa para siswa juga sudah terbiasa dalam pementasan drama, meskipun dalam melakukan dialog para siswa tersebut masih belum bisa dikategorikan mampu, namun dalam hal membuat gerakan seperti mimik wajah, dan tingkah laku lainnya, bisa dikatakan sudah berada pada kategori baik.

Berdasarkan uraian di atas, peneliti juga berkesimpulan sama, bahwa aspek non-kebahasaan para siswa sudah terlihat sangat baik dalam melakukan kegiatan 
sosiodrama, hal ini memperlihatkan mereka sudah terbiasa dengan lakon dan tindakan dalam kegiatan drama, khususnya sosiodrama, dan hal ini tentu saja membuat keterampilan siswa lebih menonjol pada aspek kebahasaan bila dibandingkan dengan aspek kebahasaan.

\section{Kesimpulan}

Berdasarkan hasil penelitian yang telah dilakukan penulis di MIN Seutui Banda Aceh, dengan judul penelitiannya yaitu "Keterampilan Berbicara Murid Kelas V MIN Seutui Banda Aceh Melalui Kegiatan Sosiodrama" maka diperoleh nilai tertinggi yang dicapai oleh siswa adalah 95 dan nilai terendah 78. Jika dilihat keterampilan siswa, terdapat 10 orang $(27,8 \%)$ siswa yang tingkat keterampilannya berada pada kategori sangat baik, 26 orang $(72,2 \%)$ siswa berada pada kategori baik dan tidak ada keterampilan siswa yang berada pada kategori sedang dan kurang. Dengan melihat keterampilan berbicara siswa melalui kegiatan sosiodrama yang berada pada kategori baik, serta menciptakan suasana yang aktif, kondusif, dan meningkatkan motivasi siswa maka kegiatan sosiodrama dapat diterapkan dalam pembelajaran bahasa Indonesia pada materi lain yang dianggap sesuai dapat diterapkan.

\section{DAFTAR PUSTAKA}

Ahmadi, Prasetya Abu, 2005. Strategi Belajar Mengajar. Bandung: CV. Pustaka. Setia

Arikunto, 2010. Prosedur Penelitian Suatu Pendekatan Praktik. Edisi Revisi, Jakarta: Rineka Cipta.

Depdiknas, 2003. Kamus Besar Bahasa Indonesia. Jakarta: Balai Pustaka. , 2006. Kurikulum Pendidikan Dasar dan Menengah, Landasan Program dan Pengembangan. Jakarta: Depdiknas. , 2008. Strategi Pembelajaran Dan Pemilihannya. Jakarta: Direktorat Tenaga Kependidikan, Direktorat Jenderal Peningkatan Mutu Pendidik Dan Tenaga Kependidikan Departemen Pendidikan Nasional.

Hamalik, O., 2007. Proses Belajar Mengajar, Jakarta: PT. Bumi Aksara.

Hasibuan. 2006. Manajemen Sumber Daya Manusia. Edisi Revisi. Jakarta: Bumi Aksara. (halaman 34,35,36 dan 38).

Nurhadi. Kurikulum 2004: Pertanyaan dan Jawaban. Jakarta: Grasindo.

Sanjaya, 2006. Strategi Pembelajaran. Jakarta: Kencana Predana Media Group.

Sunender D., 2008. Strategi Pembelajaran Bahasa. Jakarta: Departemen dan Kebudayaan

Sudjana, N., 2009. Dasar-Dasar Proses Belajar Mengajar. Bandung: Sinar Baru Algesindo.

Syafi'ie, I., 2002. Terampil Berbahasa Indonesia I. Jakarta: Departemen dan Kebudayaan.

Tarigan, 2008. Berbicara Sebagai Suatu Keterampilan Berbahasa. Bandung: Angkasa.

Tim Penyusun Kamus Pusat Bahasa, 2002. Kamus Besar Bahasa Indonesia: Edisi Ketiga. Jakarta: Balai Pustaka. 